\title{
INSURANCE PROCEEDS UNDER ABANDONED PROPERTY LAWS*
}

THROUGH abandoned property laws, states take into custody a wide variety of unclaimed property which is safeguarded for the rightful owner and utilized for the community's benefit pending a valid claim. ${ }^{3}$ The constitutionality of these laws has long been established where they apply only to liquidated obligations such as bank deposits, ${ }^{2}$ stockholder's dividends, ${ }^{3}$

* Conn. Mutual Life Ins. Co. v. Moore, 333 U.S. 541 (1948), reli'g and petition by Connecticut and Vermont for leave to intervente denied, 334 U.S. 810 (1948).

1. The amount involved is far from insignificant, the 3 year total collected in Now York alone being over $\$ 9,800,000$. See note 28 infra. Abandoned property laws are distinguishable from escheat statutes which provide for transfer of title, as well as possession, to the state. See Garrison, Escheats, Abandoned Property Acts, and Their Reventue Aspects, 35 Ky. L. REv. 302, 303-306 (1947). The effect, however, is eventually the same, since abit1doned property statutes may either prohibit claims by the owner against the state after a number of years, e.g., Minn. Srat. $\$ 7658-34$ (Mason, Supp. 1946) (10 years), or provido that funds in excess of a specified reserve fund shall become the state's absolute property. E.g., N.Y. State Finance Law $\$ 95$ (Baldwin, Supp. 1945) $(\$ 750,000)$.

Historically, escheat orignated as an incident of feudal tenure, applying only to realty. Hardman, The Law of Escheat, 4 L.Q. REv. 318 (1888). Title to personalty passed directly to the crown by virtue of its prerogative power. 7 Holdsworth, A History OF ENGLISI LAw 495-6 (2d ed. 1937). In the United States, escheat applied to both realty and personalty and was based on sovereignty rather than tenure. See Matter of People (Melrose Avo.), 234 N.Y. 48, 53, 136 N.E. 235, 237 (1922); cf. I WoERner, AMERICAN LAW OF ADMinistuTION *302-11 (importance of escheat as an adjunct to intestacy statutes). Abandoncd property legislation was interjected into this escheat background in the late nineteenth century. Garrison, supra at 306. It, too, was rooted in the soverign power of the state to talio charge of unclaimed property. See, e.g., Commonwealth v. Dollar Savings Bank, 259 Pa. $.138,145,102$ Atl. 569, 571 (1917). But, unlike escheat, abandoned property legislation found a further legal justification in the police power protection of the interests of absent owners. See cases cited note 2 infra.

The Federal Government has no general escheat power. See Klein v، Brodbeck, 15 r. Supp. 473, 474 (E.D. Pa. 1934); In re Escheat of Moneys in Custody of United States Treasury, 322 Pa. 481, 484, 186 Atl. 600, 601 (1936); cf. U.S. Const. Art. III, $\$ 3$ (outlawing forfeiture for treason except during life of person attainted). But Congress, under its plonary power in the territories, has provided for escheat of certain alien property there, 24 STAT. 476-7 (1887), as amended, 8 U.S.C. $\$ 75-6$ (1946). And installments due on federal insurance or compensation for death or disability are not paid over to a decedent's estato where escheat under state law would take place. Instead, the award is credited to tho appropriation from which it was originally made. 43 STAT. 614 (1924), as amended, 38 U.S.C. $\S 451$ (1946); 43 STAT. 625 (1924), as amended, 38 U.S.C. $\$ 514$ (1946) (term insurance under World War Veterans Act). And in one instance the effect achievable by a federal abandoned property act has apparently been attained without statutory basis, by indefinito retention of unclaimed funds involved in the liquidation of national banks. See Legis., 26 N.C. L. REv. 110-11 (1947); A Survey of Statutory Changes in N.C. in 1947, 25 N.C.L. REv. 376, 421-3 (1947).

2. E.g., Anderson Nat. Bank v. Luckett, 321 U.S. 233 (1944); Security Savings Bank v. California, 263 U.S. 282 (1923); Provident Institution for Savings v. Malone, 221 U.S. 660 (1911). Utility company deposits have been similarly treated. E.g., Brooklyn Borough Gas Co. v. Bennett, 154 Misc. 106, 277 N.Y. Supp. 203 (Sup. Ct. 1935).

3. E.g., Philadelphia Electric Co. Case, 352 Pa. 457, 43A. $2 \mathrm{~d} 116$ (1945). 
and funds paid into court registries. ${ }^{4}$ Recently, however, New York and a few other states have enacted similar statutes applicable to unliquidated and unclaimed obligations due under life insurance contracts. 5 These statutes have been attacked on the ground that the state, by talsing over the proceeds of claims which have not been established or liquidated, unconstitutionally impairs the insurer's contract rights. But in Conscclicul Mutual Ins. Co. o. Moore ${ }^{6}$ the Supreme Court upheld the New York statute in the face of such an attack and, in addition, permitted the state to sequester unclaimed proceeds of policies on the lives of New York residents issued for delivery in New York by out-of-state insurers.

Under the New York Abandoned Property Law, proceeds of insurance

4. United States v. Klein, 303 U.S. 276 (1938) (state may constitutionally escheat funds in federal court registry); $q f$. Moufang v. New York, 295 N.Y. 121, 05 N.E. $2 d 321$ (1946) (state court registry).

5. Pennsylvania enacted the first statute of this kind in 1937. Pa. Laws 1937, No. 403, p. 2063, as amended, PA. Stat. Ans., tit. 27, $\S 43 \pm$ et seg. (Purdon, Cum. Annual Supp. 1948). Subsequently, several other states followed suit. 1941: N.Y. ABandosted Prop. LAw 8700 (Baldwin, Supp. 1945). 1946: Mass. Laws Awr. c. 175, $\$ \$ 149$ A-D (1943); N.J. Stat. As:s. tit. 17 \$ 34-49 et seq. (Cum. Annual Supp. 1947). 1947: 19 MIrcr. Stıт. Asis. \$ 26.1053(5) (Cum. Supp. 1947). KY. Rev. STAT. $\$ 393.090$ (Baldwin, 1943) may also cover abandoned insurance proceeds. See Garrison, suspre note 1, at $308 \mathrm{n}$. 41. Connecticut, on the other hand, specifically exempts certain life insurance proceeds from its general escheat statute. Conn. Gen. Stat. $\$ 11$ i (Supp. 1947).

An example of how an abandoned property statute operates is provided by the Pennsylvania statute applicable, inter alia, to abandoned insurance procecds. Pa. STas. Avis, tit. $27, \$ \S 43447$ (Purdon, Cum. Annual Supp. 194S): Specifed corporations (\$ 435) must file yearly reports with the Department of Revenue listing property subject to the statute. $\$ 436$. Inquisitorial powers $(\$ 437)$ and penalties for failure to comply with those provisions (§ 441) are available as an enforcement aid. The Department notifies indicated oriners by mail and publication that their property has been reported unclaimed ( $\$ 438)$, and an index of such property is available for search. $\S 439$. Upon petition by the Attorney General and without further notice, the appropriate court may direct payment into the State Treasury. $\S 442$. Subsequent proof of legal title enables a claimant to recover securitics (\$443b), or, if in the form of money, to obtain a refund of his property with $2 \%$ interest. $\$ 2433$. In addition, subsequent proof by the transmitting company that the property was not legally subject to payment into the Pennsylvania Treasury will entitle it to a refund. $\$ 243 \mathrm{c}$. See Note, 19 N.C.L. REv. 372 (1911) (constitutional and practical requirements of a good statute).

6. 333 U.S. 341 (1948), reli'g and fetition by Connecticul and Vermons for leare to isterrene denied, 334 U.S. $\$ 10$ (194S), affirming 297 N.Y.1, 74 N.E.2d 24 (1947).

7. N.Y. Abandoned Prop. Law $\$ 700$ (Baldwin, Supp. 1945). This law has had an interesting history. Insurance policies were first subjected to abandoned property provisions in 1939. N.Y. Laws 1939, c. 923. Although the statute covered all policies regardless of where the insured resided or where the policies were delivered, it applied only to loeally incorporated companies. $I d$. $\S 295$. The statute was attacked as unconstitutional and an injunction pendente lite obtained in New Yorl: Life Ins. Co. v. Pinls, 102 N. Y. L. J. 2257 (Sup. Ct. Dec. 21, 1939). Before trial, the statute was amended to apply only to policies of domestic companies which were issued upon the lives of New Yorl: residents (N.Y. Law3 1940, c. $602 \S 295$ ), and the case was thereupon discontinued. $A 1944$ amendment extended 
policies are considered abandoned where (1) matured endowments have been unclaimed for seven years, ${ }^{8}$ or (2) beneficiaries of a deceased insured have failed to claim proceeds due for seven years, ${ }^{9}$ or (3) the insured would have attained the limiting age, under the appropriate mortality table, at which the insured can collect the face amount of the policy although still alive. ${ }^{10}$ In the Connecticut Mutual case, nine insurance companies incor* porated outside of New York sought a declaratory judgment ${ }^{11}$ that the act was unconstitutional in that satisfaction of contractual conditions such as proof of death was not required as a prerequisite to state custody, and that insurers were thus deprived of an opportunity to establish defenses which might bar or reduce their liability to a beneficiary. ${ }^{12}$ The result, plaintiffs contended, was an impairment of contracts which distinguished New York's statute from abandoned property laws involving obligations liquidated in amount. ${ }^{13}$ The Supreme Court, however, dismissed this contention by analogizing the power of a state under the instant statute to its accepted power to seize abandoned bank deposits. ${ }^{14}$ Disregarding plaintiffs' attempt to distinguish unliquidated from liquidated obligations, they characterized

this statute to foreign life insurance companies for the first time. N.Y. Laws 1944, c. 497, $\$ 1 ; i d$. c. 498 \$2. In 1945, a bill was passed to repeal the 1944 amendments and limit juris* diction, as before, to domestic companies. N.Y. Assembly Introductory No. 2268, Print No. 2551. But Governor Dewey vetoed the bill. Brief for Appellants, p. 49, 333 U.S. 541 (1948).

8. N.Y. Abandoned Prop. LaW $\S 700$ (1) (a) (Baldwin, Supp. 1945).

9. Id. $\S 700$ (1) (c).

10. This section excludes policies on which transactions have been made within seven years or on which the corporation has written evidence that the owner knows of the policy. Id. $\$ 700$ (1) (b). The limiting ages under the American Experience Table and the Commisesioners 1941 Standard Ordinary Table are respectively 96 and 100 years. 15 ENCYC. AMErICANA 201d-e (1948 ed.).

11. Plaintiffs also asked for an injunction against threatened enforcement of the statute. But the Comptroller made an injunction pendente lite unnecessary by withholding enforcement pending outcome of the case. Reply Brief for Appellants, p. 8, Conn. Mutual Life Ins. Co. v. Moore, 297 N.Y. 1, 74 N.E. 2 d 24 (1947).

12. In the lower court, plaintiffs also attacked the statute on the ground that they were deprived of the defense of the statute of limitations, but they did not attempt to argue this point in the United States Supreme Court. Perhaps they decided that their argument was foreclosed by Chase Securities Corp. v. Donaldson, 325 U.S. 304, 316 (1945) (". . . lifting the bar of a statute of limitation so as to restore a remedy lost through merc lapse of time is [not] per se an offense against the Fourteenth Amendment").

13. Plaintiffs relied on U.S. Consr. Art. $1, \S 10$, as interpreted in Green v. Biddle, 8 Wheat. 1, 83 (U.S. 1823) ("The objection to a law, on the ground of its impairing the obligation of a contract, can never depend upon the extent of the change which tho law effects in it. Any deviation from its terms, by . . . imposing conditions not expressed in the contract, or dispensing with the performance of those which are, however ininute, or apparently immaterial, in their effect upon the contract of the parties, impairs its obligation."). This interpretation is far from dormant. Cf. Worthen Co. v. Thomas, 292 U.S. 426 (1934); see Home Ins. Co. v. Dick, 281 U.S. 397, 409 (1930).

14. 333 U.S. $541,546,547$ (1948). 
the differences between claiming insurance proceeds and withdrawing deposits as mere contractual variations in the collection process. ${ }^{13}$

Perhaps plaintiffs' contentions should not be dismissed so cavalierly, for on a legalistic level the analogy relied upon by the Court is far from perfect: unlike the obligations of a bank where demand deposits are involved, ${ }^{16}$ the insurer's liability is contingent upon performance of stipulated conditions precedent. ${ }^{17}$ But vitiation of these conditions is unconstitutional only if the consequent impairment of contractual rights causes injury to the insurer which cannot be justified in the reasonable exercise of the state's police power. ${ }^{18}$ Considered from this standpoint, the Court's decision seems eminently sound.

No substantial injury to insurers results from statutory removal of the possibility that a claimant might not be able to prove compliance with a condition precedent to liability, such as proof of death or survival until maturity. ${ }^{19}$ In the case of matured endorments, ${ }^{20}$ the first class of proceeds

15. Id. at 547. It has been settled since Provident Institution for Savings v. Malone, 221 U.S. 660 (1911), that the state may enforce its claim to abandoned banls deposits without presenting the passbook required of a private claimant by the contract of deposit. The close parallel of such provisions to the condition that a claimant surrender an insurance policy before receiving its proceeds probably dissuaded plaintiffs from pressing an argument that the state should be bound by this condition. And there is no danger that presentation of the policy by a claimant after payment to the state would subject the insurer to double liability. See note 32 inafra.

16. E.g., Anderson Nat. Bank v. Luckett, 321 U.S. 233, 241, 242, 248 (1944) (deposits are debtor obligations of the bank, payable on demand).

17. Due proofs of death, age and (as to endowments) survival until maturity are required by the terms of the policies as a prerequisite to payment. Brief for Appellants, p. 3, 333 U.S. 541 (1948). These requirements are designed to give insurers a basis for intelligently estimating their liability. Lampert v. John Hancock Mutual Life Ins. Co., 28 F. Supp. 142, 143 (E.D. N.Y. 1939), aff'd nzem., 107 F. 2d 1016 (2d Cir. 1939), cerl. denied, 309 U.S. 663 (1940). They are particularly valuable as a means of protection against fraudulent claims. See VANCE, HaNdBoOK of the LAW of INSUR1NCE 337-8 (2d ed. 1930), and note 27 infra. But see p. 632 and note 29 infra.

18. Home Bld'g \& Loan Ass'n v. Blaisdell, 290 U.S. 398 (1934). Worthen Co. v. Thomas, 292 U.S. 426 (1934) apparently limited the exercise of police power in this regard to instances where an emergency existed or the impairment was only temporary. But this limitation has been progressively eaten away. E.g., Gelfert v. Nat. City Bank, 313 U.S. 221, 235 (1941) (no emergency); Veix v. Sixth Ward Bld'g \& Loan Ass'n, 310 U.S. 32, 39-40 (1910) (parmanent impairment).

There are two legal rationales by which courts justify impairment of the obligations of contract: (1) the right of the state to exercise protective powers is an implicd condition of every contract (Home Bld'g \& Loan Ass'n v. Blaisdell, sispra at 435), and (2) the police power is paramount to rights between individuals under contract. East New York Saving 3 Bank v. Hahn, 326 U.S. 230, 232-3 (1945). Both are applicable to insurance contracts. Kindleberger v. Lincoln Nat. Bank, 155 F. 2d 2S1, 2S6(D.C.Cir. 1946), cerl. dentid, 329 U.S. S03 (1947); cf. Att'y Gen. v. Provident Institution for Savings, 201 Mass. 23, 26, S6.N.E.912, 913 (1909) (implied condition rationale applied to bank deposits).

19. Plaintiffs also included proof of age as a condition precedent (see note $17 \mathrm{sispra),}$ but nowhere specified the reason why they classified it as such. Rather, misstatement of age is an affirmative defense on which the insurer, not the beneficiary; bears the burden of 
which can be sequestered under the statute, the only condition to be estab. lished by a claimant is proof of survival-evidence relevant only to the issue of who may claim the proceeds; it does not affect the amount of an insurer's liability, which is already fixed. ${ }^{21}$ In the second class, life policies merely awaiting the claim of a beneficiary, insistance on the condition precedent of proof of death would usually be meaningless: by definition the statute applies only where death of the insured has already been verified by the companies. ${ }^{22}$ And in the third category, where the insured would have attained the limiting age under the mortality table, ${ }^{23}$ any possibility that liability could not be established is minimized by numerous presumptions ${ }^{24}$ which enabla skeletal proof of death ${ }^{25}$ to constitute compliance with the contract. ${ }^{26}$

proof. Silberman v. Wash. Nat. Ins. Co., 329 Ill. App. 448, 69 N.E. 2d 519 (1946); see VANCE, op. cit. supra note 17 at 963-5 (reproducing a typical life insurance policy). But $c$. Hervitz v. New York Life Ins. Co., 160 Pa. Super. 496, 52 A. 2 d 368 (1947) (claimant pleaded age rather than relying on the presumption and thus invited the burden of proving the issuu). See note 27 infra.

20. See p. 630 supra.

21. The face amount of an endowment policy is paid to the insured if he survives and to the beneficiary if the insured dies before maturity. HUEBNER, LIFE INSURANCE 95 (1925). There is a so-called "pure endowment" in which nothing is paid unless the holder lives until maturity. What the disposition of such a policy would be under the statute does not appear. Plaintiffs did not argue the point, probably because such policies are relatively rare. Id. at 171 .

22. N.Y. Abandoned Prop. Law $\S 700$ (1) (c) (Baldwin, Supp، 1944).

23. See note 10 supra.

24. E.g., Mutual Life Ins. Co. v. Hamilton, 143 F. $2 d 726$ (5th Cir, 1944), cert. denticd, 323 U.S. 760 (1944) (proof of seven years' unexplained absence complies with due proof of death clause); Cutrell v. John Hancock Mutual Life Ins. Co., 145 Neb. 550, 17 N.W. 2d 465 (1945) (presumption against death by suicide or murder); Pacific Mutual Life Ins. Co. v. Meade, $281 \mathrm{Ky} .36,134$ S.W. 2d 960 (1939) (habits and character remain the same); Now York Life Ins. Co. v. Carroll, 154 Okla. 244, 7 P. 2 d 440 (1932) (answers in application aro not fraudulent). These presumptions do not deny due process. E.g., Mobile, J.\&K.C. R.R. v. Turnipseed, 219 U.S. 35 (1910).

25. E.g., Bernstein v. Metropolitan Life Ins. Co., 139 Me. 388, 34 A. 2 d 682 (1943) (death may be proved by circumstantial evidence even where policy stipulates proof of actual death); Kundiger v. Metropolitan Life Ins. Co., 218 Minn. 273, 15 N.W. $2 \mathrm{~d} 487$ (1944) (substantial compliance is sufficient); Apfelbaum v. Prudential Ins. Co., 12 Misc. 62 (N.J. Sup. Ct. 1933), aff'd, 169 Atl. 677 (1933) (no proofs filed at all, but company had all the information that claimant had); McCaffry v. Metropolitan Life Ins. Co., 261 App. Div. 452, 25 N.Y.S. 2d 926 (2d Dep't 1941) aff'd 287 N.Y. 704 (1942) (blanks in forms whild seek to elicit cause, as distinguished from circumstances, of death may be ignored); Hanrahan v. John Hancock Mutual Life Ins. Co., 143 Pa. Super. 557, 18 A. 2 d 512 (1941) (duo proof need not be in any particular form, or strongest or best proof available, as long as essential facts on which insurer's liability depends are given). Even though compliance with proof of loss is stipulated as a condition precedent, courts may excuse non-compliance. Hulme v. Mutual Benefit Health \& Accident Ass'n, 60 Ga. App. 65, 2 S.E. 2d 750 (1939). See Note, Due Proof of Death in Life and Accident Instrance Policies, 28 Iows L. Rrv. 683 (1943).

26. Moreover, an alternative to proof of death in this third category is proof that the insured individual actually attained the limiting age under the mortality table. Either event brings the policy to maturity and crystallizes the insurer's liability. See Life Ins، Nows 
In an effort to lend an aura of significance to their conditions precedent, plaintiffs alleged that a claimant's proof of death might uncover facts leading to various defenses which otherwise could not be established. 7 This argument, however, assumes not only that claims would be made but also that the basic facts presented by the claimants would lead to defenses. Except where this double-barreled hypothesis would become a reality in the absence of state sequestration of the proceeds, the insurer has not been injured. Yet experience indicates that no claim will ever be made ${ }^{3}$ or defense established ${ }^{29}$ to the vast majority of abandoned policies.

Data, Nov. 24, 1948, col. 5. (50 life insurance policy holders over 95 years old will themselves collect for the face amount on policies maturing for age in 19:9).

27. Brief for Appellants, p. 4, Conn. Mitual Life Ins. Co. y. Moore, 333 U.S. 541 (1948) ("Since no one knows whether the insured is living or dead, or if dead, when or how he died, it is impossible to know or determine the amount of liability, if any, in the absence of the due proofs required by the terms of the policies."). See the due proof of accidental death provision quoted in Lampert v. John Hancock MIutual Life Ins. Co., 28 F. Supp. 142, 143 (E.D. N.Y. 1939), aff'd ment., 107 F. 2d 1016 (2d Cir. 1939), cert. denied, 309 U.S. 663 (1940).

Death under a circumstance excepted by the policy is particularly susceptible to discovery from claimant's proof of death. See, e.g., Egsena v. New Yorl: Life Ins. Co., 236 Iowa 262, 18 N.W. 2d 530 (1945) (military service); Hembree v. American Ins. Union, 121 Kan. 271, 246 Pac. 683 (1926) (pregnancy); Washington v. Univerzal Life Ins. Co., 157 So. 162 (La. App. 1934) ("resisting officers of the law"); Honrath v. New Yorls Life Ins. Co., 65 S.D. 480,275 N.W. 258 (1937) (suicide). Fraudulent misstatements or breach of policy" provisions may also be ascertained. E.g., Sortito v. Prudential Ins. Co., 10S Conn. 163, 142 Atl. S08 (1928) (good health when policy issued); Metropolitan Life Ins. Co. v. Plunlett, 129 Okla. 292, 261 Pac. 827 (1928) (insanity); Gardocki v. Polish Nat. Alliance, 141 Pa. Super. 53, 14 A. 2d 604 (1940) (intemperance).

Another defense which may be uncovered is misstatement of age by the insured. See note 19 supra. If established, it reduces the amount of liability. N.Y. Ixsurulice Law $\S 155$ (1) (d) (Baldwin, Supp. 1941); New York Life Ins. Co. v. Veit, 294 N.Y. 222, 62 N.E.2d 45 (1945) (reduction from $\$ 25,000$ to $\$ 15,077$ ). The insurer must overcome a presumption, however, that the age stated in the policy is correct. Goell $v$. United State Life Ins. Co., 265 App. Div. 735, 40 N.Y.S. 2d 779 (1st Dep't 1943).

28. In the years 1945-7, New York received from all sources a total of $\$ 9, \$ 67,0 \$ 4.26$ into its abandoned property fund, more than 96 percent of which has never been reclaimed from the state. See REP. Cosiptroller 105-6 (N.Y. 1945); id. at 107-S (1946); id. at 113-14 (1947). Receipts from locally incorporated insurance companies, the only ones covered in the statute until the present case, in the same years totaled $\$ 2 \$ 7,094.09$. Id. at 106 (1945); id. at 108 (1946); id. at 114 (1947).

29. The obstacles to a successful delense are imposing. Recomizing that insurance companies have primary control over the terms of their contracts, courts have strictly interpreted the wording against insurers. Williston and Thompson, Selectrons frous Wrurston's Contracts 494, 614 (rev. ed. 1938); see, e.g., Bergholm v. Peoria Life Ins. Co., 284 U. S. 489, 492 (1932) (rule conversely stated as one of liberal construction in claimant's favor). In addition, courts have sought to limit defenses by presumption such as those listed in note 24 supra. And burden of proof presents another obstacle: although the claimant ordinarily has the burden of proving compliance with proof of death as part of his prima facie case, Howe v. Nat. Life Ins. Co., 321 Mass. 283, 72 N.E. $2 d 425$ (1947), the breach of any particular condition then becomes an affirmative defense which must be pleaded and proved by the insurer. E.g., Tkatch v. Knights \& Ladies of Security, 264 Pa. 578, 107 Atl. 
Only rarely, therefore, does the statute actually deprive insurance companies of an opportunity to ferret out defenses which they have not already discovered. And where they do have present defenses, there is no requirement that the proceeds be handed over to the state. ${ }^{30}$ Nor is there danger that the companies will in fact lose money on the policies. They have already had the profitable use of the premiums for substantially longer than if the proceeds had been promptly claimed. ${ }^{31}$ Moreover, a discharge granted by the state relieves the company of liability to a subsequent claimant. ${ }^{82}$

Thus the only substantial impact upon the insurers is that they are not permitted to retain the windfall-a result which is indeed the objective of all abandoned property laws. The companies contended that the profit created by an owner's failure to claim his property should inure to the benefit of other policyholders. ${ }^{33}$ But no reason is apparent why insurance policyholders should be entitled to benefits which their counterparts,

890 (1919). But of. Bennett v. Royal Union Mutual Life Ins. Co., 232 Mo. App. 1027, 112 S.W. 2d 134 (1938) (by alleging circumstances under which premiums were paid, claimant assumed burden of proof on question of lapse).

One expert predicts that this trend is increasing: "The future litigation of insurance claims will . . . turn more upon the substantive merits or defects of the claim and less upon technical breaches of condition which sometimes concealed the real issues in controversy." Patterson, Insurance, 8 Significant Developments in the Law 37 (P.L.I. Pam,, 1946).

30. This interpretation of the statute was made by the New York court in the instant case: "The plaintiff companies . . cannot resist payment . . . because of (1) the Statute of Limitations or (2) noncompliance with policy provisions calling for due proof of death or of other designated contingency or (3) failure to surrender a policy. Except for these restrictions, however, the statute $(\$ 700)$ leaves any of the plaintiff companies wholly free to set up any complete or partial defense .. ." Conn. Mutual Life Ins. Co. v. Moore, 297N.Y.1, 10-11, 74 N.E. 2d 24, 27-28 (1947). On appeal, plaintiffs abandoned arguments based on the statute of limitations and policy surrender requirements. See notes 12 and 15 stipra.

31. Under the New York statute, seven years is the minimum of extra time during which the insurer has use of the premiums. See page 630 supra. In two of the three classifications, where endowments have matured and where the limiting age has been reached, tho companies actually make a profit since they hold the premiums for a longer time than is necessary to accumulate the face amount of the policy. These gratuities should more than offset the conjectural possibility that the insurer might have uncovered a valid clefenso to an abandoned policy if the state had not taken the proceeds into custody.

32. N.Y. Abandoned Property Law $\$ 1404$ (2) (Baldwin, Supp. 1943); cf. Security Savings Bank v. California, 263 U.S. 282 (1923) (payment to the state in obedienco to a valid abandoned property law discharges an obligor). New York has a provision which allows an insurer who nevertheless pays a claimant to acquire the claimant's rights against the state. N.Y. Abandoned Property LAW $\$ 707$ (Baldwin, Supp. 1947).

33. Brief for Appellants p.25, 333 U.S. 541 (1948). Since the bulk of life insurance is carried in mutual companies, 15 ENCYC. AmERICANa 196 (1948 ed.), policyholders would usually receive the windfall as an item of profit payable, for example, in the form of a deduction from premiums or a paid-up addition to their policies. See N.Y. INSURANCE LAW $\$ 216$ (2) (Baldwin, Supp. 1941) Holders of participating policies in stock companies would sim. ilarly benefit. $I d . ~ \$ 216(1)$. And stockholders in the latter companies would presumably receive increased dividends. 
mutual bank depositors ${ }^{38}$ or utility company stockholders, ${ }^{35}$ have already been denied by decisions upholding other abandoned property laws.

In realistic terms, therefore, the Supreme Court was correct in treating insurance proceeds identically with bank deposits. There is no reason why the public should not be the beneficiary in both instances. The state's custodial power justifies the initial act of taking the proceeds away from the companies to hold for potential claimants." And a windfall resulting from subsequent failure of claimants to materialize is in the nature of ownerless property which the state is entitled to retain. ${ }^{37}$

While no dissenting voice was raised to the merits of the decision on impairment of contractual rights, three justices felt that no declaratory judgment at all should be issued in view of their uncertainty as to whether New York possessed constitutional power to take over proceeds held by foreign insurance companies. As construed by the state court, the statute embraced all abandoned policies issued for delivery in New York on the lives of persons then resident there. ${ }^{3 s}$ Refusing to rule on its entire scope, however, the majority confined its decision to instances where both the insured and beneficiaries continued to reside in New York until the policy matured. Six Justices agreed that in this hypothetical situation New York had "sulficient contact with the transaction" to justify its intervention.s3 But three Justices balked at even this limited holding: 0 Their primary ground was the

34. E.g., Provident Institution for Savings v. Malone, 221 U.S. 660, 665 (1911) (fact that mutual despositors on dissolution of the institution share abandoned funds left in the bank does not require that the state refrain from taking such funds into custody); Grecnough v. Peoples Savings Bank, 38 R.I. 100, 94 Atl. 706 (1915).

35. E.g., Philadelphia Electric Co. Case, 352 Pa. 457, 43 A. 2d 116 (19:5) (abandoned stock).

36. Protection of an absentee's property under the police power is the basis for all abandoned property legislation. See note 1 and cases cited note 2 supra; Garrison, suspra note 1 , at 310; $f$. Blinn v. Nelson, 222 U.S. 1 (1911); Cunnius v. Rcading School District, 198 U.S. 458 (1905).

Other countries exercise similar powers. Sce Cunnius v. Reading School District, stspro at 469-71 (discussing law of France, Germany and England).

37. The fundamental principle behind both escheat and abandoned proparty laws is the feeling that the community at large should profit from a windfall rather than an individual or a limited group of stock or policy holders. See In re Harrisburg Bridge Co., 33 Pa. D.\&C. 657, 661-2 (1940), and note 1 supra.

38. The terms of the statute cover any policy issued on the life of a New Yoris resident. N.Y. Abandoned Prop. Law $\$ 700$ (Baldwin, Supp. 19:5). But the New Forl: Supreme Court declared the act invalid ". . . in so far as it purports to apply to policies vritten outside of the state by foreign companies . . ." upholding it only as to policies iasued for delivery in New York. Conn. Mut. Life Ins. Co. v. Moore, 187 Misc. 1001, 1016, 65 N.Y.S. 2d 143, 155 (Sup. Ct. 1946), aff'd mem., 271 App. Div. 1002, 69 N.Y.S. $2 d 323$ (1st Dep't 1947), aff'd, 297 N.Y.1, 74 N.E. 2 d, 24 (1947), aff'd, 333 U.S. 541 (1943).

39. 333 U.S. 541, 548-50 (1948).

40. Mr. Justice Douglas joined in a dissent written by Mr. Justice Jackson. Id. at 550. While indicating substantial agreement with this opinion, Mr. Justice Franlsfurter elabornted on his own views in a separate dissent. Id. at 551 . 
potential conflict with statutes which, like that of Pennsylvania, assert power to take proceeds into custody on bases such as domicil of the insurer. ${ }^{41}$ Thus, if a policy issued by a Pennsylvania insurer should fall within the scope of the New York statute as approved by the Conneclicul Mutual decision, abandoned proceeds would be subject to the claims of both states. ${ }^{48}$ To hold that New York had "sufficient contacts," the dissenting Justices contended, placed the Court in a dilemma. Consistency would require either judicial denial of Pennsylvania's power to enforce its statute despite equally close "contacts," or unconstitutional imposition of double liability on insurers. ${ }^{43}$

This argument, however, neglects the possibility of sanctioning a race of diligence among states having "sufficient contacts." 44

Admittedly, such a race has practical disadvantages: if a premium were placed on diligence, each legislature would seek to take proceeds into custocly after a shorter waiting period than its rivals, ${ }^{45}$ and the ensuing confusion should result in extensive litigation ${ }^{46}$ as well as conflicting claims against the insurers. ${ }^{47}$ But since these difficulties become acute only when conflicting claims are numerous, the Connecticut Mutual decision presents no practical obstacle to upholding the Pennsylvania statute. Rarely could New York establish continued residence by both insured and beneficiaries of out-of-state policies.

Nor does the Connecticut Mutual decision present any theoretical obstacle to validating the Pennsylvania type of statute. The criterion of this statute,

41. Pa. Stat. Ann., tit. 27, § 434 el seq. (Purdon, Cum Annual Supp. 1947); $c f$. Mass, Laws Ann. c. 175, $\$ 149$ A-D (1948); N.J. Stat. AnN., tit. 17, $\$ \S 34-49$ (cum. Annual Supp. 1947).

42. An intermediate basis, potentially conflicting with that of both New York and Pennsylvania, is utilized by the Michigan statute. $19 \mathrm{MICH}$. STAT. ANN. $\$ \$ 26.1053(1)-(66)$ (Cum Supp. 1947). Like New York, Michigan seeks certain policies of forcign insurers. $\$ 26.1053(5) a$. But any resemblance to either New York or Pennsylvania ceases there, for Michigan takes custody of the proceeds on the basis of the "owner's" $(\$ 26.1053(5) \mathrm{c})$ residence without regard to any other factor. Foreign companies doing business in Michigan must report the property of an owner whose last known address indicated a Michigan residence. $\$ 26.1053$ (6). Thus, a Pennsylvania policy may be subject to claim by Pennsylvania on the basis of the insurer's domicile, by New York on the basis of issuance for delivery and residence of the insured, and by Michigan on the basis of the owner's last residence.

43. 333 U.S. 541, 560 (1948).

44. Under this alternative, the state first procuring the proceeds would retain them in full, subject to possible allocation among claiming states through agreement, arbitration, or otherwise.

45. Too short a period might have the unfortunate consequence of encouraging efforts of claimants to avert defenses by "disappearing" until after the state has taken proceeds into custody and then asserting their claim, free from defenses, against the state.

46. Particularly would this be true where factors as difficult to establish as "issutunce for delivery" and "residence" of the insured and beneficiaries constitute the basis of one state's claim.

47. In addition to this burden the insurance companies could be required to process records and reports for whatever states alleged jurisdiction over their policies. 
location of the insurer's home office," satisfies the test of "sufficient contacts" more than any other basis of custodial power: the entire insurance transaction centers, ${ }^{49}$ and the proceeds are located, 19 in the state of the home office. Thus, a stringent definition of "sufficient contacts" would preserve the Pennsylvania statute, establishing a basis on which every policy could be reached by some state. At the same time, such a definition could bar statutes based on less substantial grounds and thereby obviate all but a few conflicting claims. ${ }^{51}$

Now that it has been authoritatively determined that unclaimed insurance proceeds may be treated as an item of abandoned property, expansion of general statutes to encompass this source of non-tax revenue can be expected. Although the Connecticut Mutual opinions afford little guidance as

48. "Home office" of the insurer does not signify mere technical domicile consisting solely of a post-office box in some state with favorable incorporation laws. Factually insurance companies bear a far more significant relationship to their incorporating state. See note 49 infra. Pennsylvania relies on this "home office" criterion, since its statute embraces all insurers incorporated and doing business under the Commonwealth's laws. PA. STar. Avw., tit. 27, $\$ 435$ (Purdon, Cum. Annual Supp. 1948).

49. See Conn. Mut. Ins. Co. v. Moore, 187 Misc. 1004, 1009-10, 65 N. Y.S. 2d 143, 148-9 (1946): ". . . [T]he business of plaintiffs is conducted from their Home Offices, located in the states of their incorporation, where their officers, records, and securitiss are situated; . . . applications . . . [are considered and approved, and] policies are written at the Home Offices and sent to the agents for delivery to the applicants. Premiums are payable at the Home Offices, or, if paid to agents, are forwarded to the Home Offices. Notices as to premiums coming due and as to policy loans, interest on policy loans, lapses, etc.n are mailed from the Home Offices. Loans on policies are considered and made at the Home Offices, and loan checks are drawn at the Home Offices and mailed to the policy holders, or to agents for delivery to policy holders. 'Claims under policies must be made at the Home Offices, under the terms of the policies, which provide that upon recejpt at the Home Ofice of 'due proof' of death, or other event, the company will pay, etc., and all claims are considered at the Home Offices, and, if allowed pursuant to the terms of the policies, are paid by checks drawn at the Home Offices." "The convergence of such numerous contasts within one jurisdiction is an important consideration in view of the uniformity objcetives behind conflict of laws rules. See Harper, Policy Bases of the Conflict of Larrs, 56 YALE L.J. $1155,1163-4$ (1947).

50. Situs of the abandoned property is the usual criterion of state dominion. Sce cases cited note 2 supra. Domicile of the owner was specifically rejected in favor of actual dominion over the res as a basis for escheat in In re Rapoport's Estate, 317 Mich. 291, $26 \mathrm{~N} . \mathrm{WW}$. 2d 777 (1947). Contra: In re Lyons' Estate 175 Wash. 115, 26 P.2d 615 (1933), criticiced in 47 HARv. L. REv. 872 (1934).

In United States v. Klein, 303 U.S. 276 (1938), funds held in the United States Distrist Court in Pennsylvania were declared a proper subject for escheat by Pennsylvaniz. Since the funds had already been deposited with the U.S. Treasury, it might be argued that a mere constructive presence was sanctioned. It is clear, however, that the district court had control of the funds as a credit in its registry and that the circuit court conceived of the aetual situs as Pennsylvania. 106 F. 2d 213 (3d Cir. 1939), cerl. denicd, 308 U.S. 618 (1939).

51. The New York statute, except as to the limited situation approved by the instant case, might well be invalidated on this ground. See page 635 supro. For discussion of the innumerable factors on which statutes might be based, see Mr. Justice Jackson's dicsent, 333 U.S. 541, 558-9 (1948). 